\title{
Rapid identification of filamentous actinomycetes to the genus level using genus-specific 16S rRNA gene restriction fragment patterns
}

\author{
Andrew E. Cook and Paul R. Meyers \\ Department of Molecular and Cell Biology, University of Cape Town, Private Bag 1, \\ Rondebosch, 7701, Cape Town, South Africa
}

Correspondence

Paul R. Meyers

pmeyers@science.uct.ac.za

\begin{abstract}
A rapid method for identifying filamentous actinomycete genera was developed based on $16 \mathrm{~S}$ rRNA gene restriction fragment patterns. The patterns were generated by using specific restriction endonucleases to perform in silico digestions on the 16S rRNA gene sequences of all validly published filamentous actinomycete species. The method was applied to identifying actinomycete isolates from soil. Amplified 16S rDNA of soil actinomycetes was restricted with selected endonucleases and electrophoresed on agarose gels. The restriction fragment patterns of the unknown isolates were easily compared to the established patterns. Significantly, the genus Streptomyces could be differentiated from all other actinomycete genera by using only four restriction endonucleases, Sau3Al, Asnl, Kpnl and Sphl. This could be achieved in a time period of as little as a week, following PCR-template DNA isolation by a simple method. The identification method allowed unknown, non-Streptomyces soil isolates to be identified to a genus or small subgroup of genera. The genera in these subgroups could, in some cases, be distinguished by virtue of colony-morphology differences.
\end{abstract}

\section{INTRODUCTION}

Actinomycetes are widely distributed in terrestrial environments and have long been a source of commercially useful enzymes and therapeutically useful bioactive molecules. Since molecular structure determines molecular function, and molecular diversity underpins the diversity of life on Earth, it follows that identifying biological diversity increases the chances of identifying novel molecules. In the case of bacteria, identifying new species and genera increases the chances that any bioactive molecules produced by such organisms are unknown to science (Lazzarini et al., 2000).

The traditional methods used for the identification of the aerobic filamentous actinomycetes are laborious, timeconsuming and often require a series of specialized tests (Steingrube et al., 1995b, 1997; Wilson et al., 1998; Harvey et al., 2001). Chemical criteria, such as the isomer of diaminopimelic acid (DAP) present in the cell wall and the diagnostic sugar(s) present in the whole-cell hydrolysate, have been used to separate the actinomycete genera into broad chemotaxonomic groups. However, determination of

Published online ahead of print on 16 May 2003 as DOI 10.1099/ ijs.0.02680-0.

Abbreviation: DAP, diaminopimelic acid.

An interactive Microsoft PowerPoint (version 5.0) presentation of the in silico procedure described in this article is available in IJSEM Online. these characteristics is time-consuming and, in most cases, cannot identify an isolate to a single genus (Lechevalier, 1989).

PCR-based methods have provided a rapid and accurate way to identify bacteria (Gurtler et al., 1991; Kohler et al., 1991; Beyazova \& Lechevalier, 1993; Telenti et al., 1993; Soini et al., 1994; Mehling et al., 1995; Steingrube et al., 1995a, 1997; Wilson et al., 1998; Laurent et al., 1999). In particular, amplified rDNA restriction analysis (ARDRA) has proved to be very useful (Harvey et al., 2001; Alves et al., 2002).

ARDRA has been shown to be useful in differentiating between bacterial species within a genus, for example, Clostridium (Gurtler et al., 1991), and in differentiating bacterial strains within a species, for example, Lactococcus (Kohler et al., 1991). It has also been shown to be useful in identifying several medically important species of aerobic actinomycetes belonging to the genera Actinomadura, Gordonia, Nocardia, Rhodococcus, Saccharomonospora, Saccharopolyspora, Streptomyces and Tsukamurella (Steingrube et al., 1997; Wilson et al., 1998; Harvey et al., 2001; Laurent et al., 1999).

By conventional isolation methods, members of the genus Streptomyces comprise more than $95 \%$ of the filamentous actinomycete population in soil (Lacey, 1973; Elander, 1987). The streptomycetes produce more antibiotics than any other genus of bacteria and, therefore, have been heavily 
exploited as a source of novel antimicrobial agents (Watve et al., 2001). The probability of isolating known species of Streptomyces from the environment is thus great and the probability of isolating novel antibacterial molecules from such species is very low. The isolation of the rarer, nonStreptomyces actinomycetes greatly increases the probability of isolating novel antibacterial molecules (Lazzarini et al., 2000). Therefore, a rapid method to distinguish streptomycetes from other actinomycetes and to identify the nonstreptomycetes to the genus level would be extremely useful. This would be of particular value in discerning between streptomycetes and non-streptomycetes, such as Actinomadura, Nocardia and Nocardiopsis, whose colonies may be morphologically similar on agar plates.

We have developed a rapid method to identify filamentous actinomycetes to the genus level in less than a week, following DNA isolation from a pure culture. The method was tested on unknown actinomycetes isolated from soil and can be pursued at moderate cost in any laboratory possessing simple molecular-biology equipment and reagents.

\section{METHODS}

Data collection. A database containing 16S rRNA gene sequences of all validly published filamentous actinomycetes (Euzéby, 2002) was compiled from GenBank (http://www.ncbi.nlm.nih.gov). All sequences used were longer than $1400 \mathrm{bp}$. The sequences were grouped by genus according to Stackebrandt et al. (1997) and the NCBI Taxonomy Browser (http://www.ncbi.nlm.nih.gov/Taxonomy/ Browser/wwwtax.cgi).

In silico restriction endonuclease digestions. Thirty-eight restriction endonucleases were selected. All conformed to the dual requirements of being commercially available and recognizing a specific sequence $(4,6$ or $8 \mathrm{bp})$ in which every nucleotide position is defined. In silico digestions were performed on each sequence using DNAMAN (version 4.13; Lynnon Biosoft). The in silico analysis allowed for the selection of specific restriction endonucleases that would allow actinomycete genera to be distinguished.

Organisms and culture conditions. Soil actinomycetes were isolated on Czapek Solution Agar (Atlas, 1993), Middlebrook 7H9 Agar (Difco Laboratories) or Streptomyces General Defined Medium [GM $(800 \mathrm{ml}): 0 \cdot 17 \mathrm{~g} \mathrm{Na}_{2} \mathrm{HPO}_{4} \cdot 2 \mathrm{H}_{2} \mathrm{O}, 0 \cdot 14 \mathrm{~g} \mathrm{KH}_{2} \mathrm{PO}_{4}, 0 \cdot 05 \mathrm{~g} \mathrm{MgSO}_{4} .7 \mathrm{H}_{2} \mathrm{O}$, $0.01 \mathrm{~g} \mathrm{FeSO}_{4} .7 \mathrm{H}_{2} \mathrm{O}$; pH $7 \cdot 0$; autoclaved at 15 p.s.i. $(103 \cdot 5 \mathrm{kPa})$ for $15 \mathrm{~min}$; after cooling, $100 \mathrm{ml}$ of $100 \mathrm{mM}$ glucose, $50 \mathrm{ml}$ of $50 \mathrm{mM}$ $\left(\mathrm{NH}_{4}\right)_{2} \mathrm{SO}_{4}$ and $50 \mathrm{ml}$ of $50 \mathrm{mM} \mathrm{L}$-glutamic acid, sodium salt, were added)]. All media contained cycloheximide at $50 \mu \mathrm{g} \mathrm{ml}^{-1}$. Cultures were incubated at $30^{\circ} \mathrm{C}$ for $14-28$ days. Colony selection was based on the colour of aerial and substrate mycelium, differences in morphology and rate of growth.

DNA extraction. Actinomycete strains were grown in $10 \mathrm{ml}$ International Streptomyces Project Medium 1 (ISP 1) (Shirling \& Gottlieb, 1966) with agitation at $30{ }^{\circ} \mathrm{C}$ for $18-24 \mathrm{~h}$ and examined by Gram stain. Cells $(4 \mathrm{ml})$ were harvested by centrifugation $(7500 \mathrm{~g}$ for $2 \mathrm{~min}$ ), washed once with $500 \mu \mathrm{l}$ of $10 \mathrm{mM}$ Tris- $\mathrm{HCl} / 1 \mathrm{mM}$ EDTA (TE) buffer (pH 7.7) and resuspended in $500 \mu \mathrm{l}$ TE buffer $(\mathrm{pH} 7 \cdot 7)$. The samples were heated in boiling water for $10 \mathrm{~min}$, allowed to cool for $5 \mathrm{~min}$ and centrifuged $(7500 \mathrm{~g}$ for $3 \mathrm{~min}$ ). The supernatant $(300 \mu \mathrm{l})$ was transferred to a clean tube and stored at
$4{ }^{\circ} \mathrm{C}$. If melanin or other pigments were produced during growth in ISP 1 , cultures were grown in Middlebrook 7H9 broth, as these pigments interfered with the PCR.

PCR amplification. PCR was carried out in $50 \mu \mathrm{l}$ volumes containing $2 \mathrm{mM} \mathrm{MgCl}_{2}, 2 \mathrm{U}$ Taq polymerase (JMR Holdings, USA), $150 \mu \mathrm{M}$ of each dNTP, $0.5 \mu \mathrm{M}$ of each primer and $2 \mu$ l template DNA. Primer F1 ( $5^{\prime}$-AGAGTTTGATCITGGCTCAG- $3^{\prime}$; I = inosine) and primer R5 (5'-ACGGITACCTTGTTACGACTT-3') were modified from primers $\mathrm{fD} 1$ and $\mathrm{rP} 2$, respectively, of Weisburg et al. (1991). Primer F1 binds to base positions $7-26$ and primer R5 to base positions 1496-1476 of the 16S rRNA gene of Streptomyces ambofaciens ATCC $23877^{\mathrm{T}}$ ( $\mathrm{rrnD}$ operon; GenBank accession no. M27245). The primers were used to amplify nearly full-length $16 \mathrm{~S}$ rDNA sequences. The PCR programme used was an initial denaturation $\left(96^{\circ} \mathrm{C}\right.$ for $\left.2 \mathrm{~min}\right), 30$ cycles of denaturation $\left(96^{\circ} \mathrm{C}\right.$ for $45 \mathrm{~s}$ ), annealing $\left(56^{\circ} \mathrm{C}\right.$ for $\left.30 \mathrm{~s}\right)$ and extension $\left(72^{\circ} \mathrm{C}\right.$ for $\left.2 \mathrm{~min}\right)$, and a final extension $\left(72^{\circ} \mathrm{C}\right.$ for $\left.5 \mathrm{~min}\right)$. The PCR products were electrophoresed on $1 \%$ agarose gels, containing ethidium bromide $\left(10 \mu \mathrm{g} \mathrm{ml}^{-1}\right)$, to ensure that a fragment of the correct size had been amplified.

Restriction endonuclease digestions and analysis. PCRamplified DNA for Sau3AI digestion was purified using the QIAquick PCR Purification Kit (Qiagen). No pre-treatment of the DNA was required for the other restriction endonucleases. Restriction digestions were incubated at $37^{\circ} \mathrm{C}$ for $3-4 \mathrm{~h}$. Samples were electrophoresed on $1.5 \%$ agarose gels containing ethidium bromide $\left(10 \mu \mathrm{g} \mathrm{ml}^{-1}\right)$. The restriction fragment patterns were compared manually with those from the in silico restriction endonuclease digestions.

\section{RESULTS AND DISCUSSION}

\section{The rapid identification method}

Four hundred and four (404) validly published filamentous actinomycete $16 \mathrm{~S}$ rRNA gene sequences were downloaded from the GenBank database. Based on the in silico results, a set of 13 restriction endonucleases was selected empirically for use in the design of the rapid genus identification method. All sequence sites recognized by these endonucleases occur outside the $\alpha, \beta$ and $\gamma$ variable regions of Streptomyces 16S rRNA genes (Anderson \& Wellington, 2001).

Sau3AI was the first restriction endonuclease used, as it divided the filamentous actinomycetes into three major groups (Fig. 1). Most genera were placed in a single Sau3AI group. However, the genera Gordonia, Microbispora, Nocardia and Nonomuraea were represented in Groups 1 and 3; Nocardiopsis, Saccharomonospora, Saccharopolyspora, Streptosporangium and Thermomonospora were represented in Groups 2 and 3. Members of the genera Nocardioides and Pseudonocardia were distributed across all three groups. The distribution of genera across two or all three Sau3AI groups arose as a result of mutations that created a new Sau3AI recognition site or destroyed a genus-characteristic Sau3AI site. Whether this reflects true sequence differences or sequencing error is not known. The Sau3AI group in which the majority of species of a genus are placed is considered characteristic of that genus. 


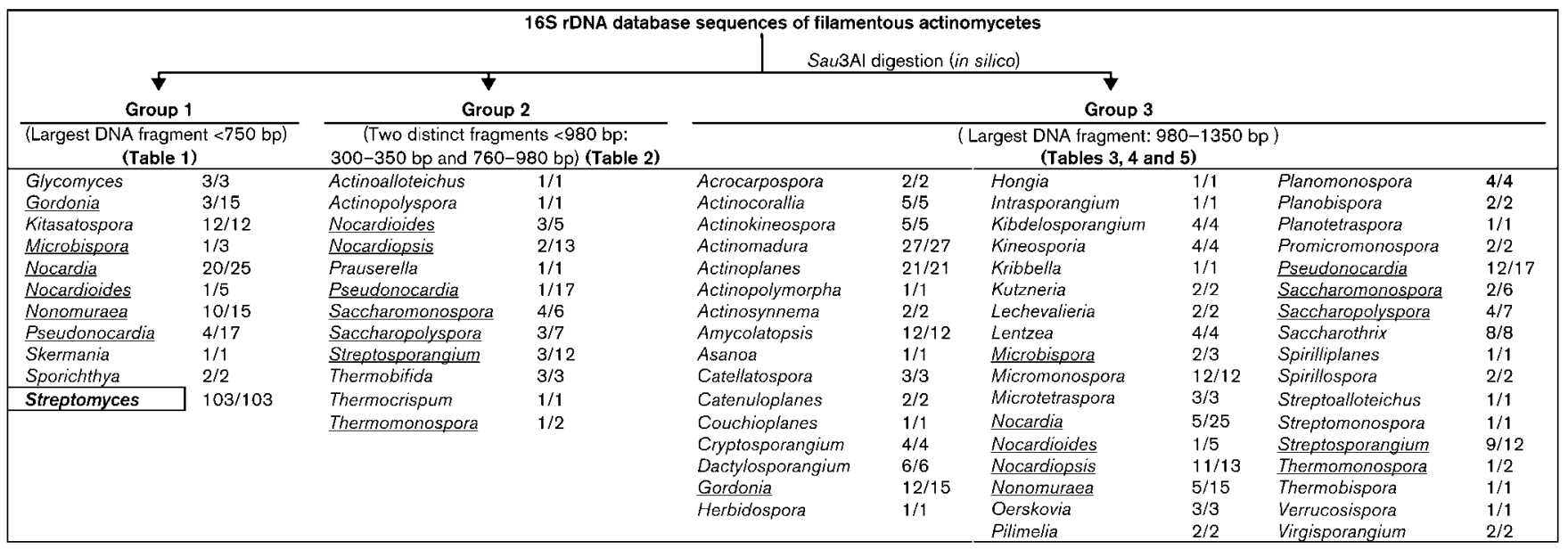

Fig. 1. Chart showing the three groups of actinomycete genera formed after the Sau3Al in silico digestion. The numbers after each genus indicate how many species of that genus exhibited that banding pattern. For example, in Group 1, three Gordonia species, out of 15 analysed, produced a large band of less than $750 \mathrm{bp}$. Underlined names indicate genera represented in more than one Sau3Al group.

A series of dichotomous keys was developed to identify rapidly the genera within the three Sau3AI groups. Table 1 allows the identification of the actinomycete genera in Sau3AI Group 1. An unknown Streptomyces isolate could be identified by the sequential use of four restriction endonucleases: Sau3AI, AsnI, KpnI and SphI (Table 1). Although the genus Streptomyces could not be differentiated from the extremely rare genus Sporichthya based on the 16S rRNA gene restriction analysis (Table 1, 4b), the morphology of Sporichthya clearly distinguishes it from the genus Streptomyces (Tamura et al., 1999). The genus Skermania and some members of the genera Gordonia and Nocardia formed a subgroup (Table 1, 6b), which could not be resolved. The genus Nocardia belongs to the family

Table 1. Identification of the genera in Sau3Al Group 1

The number in parentheses after each genus name indicates how many species of that genus follow that specific pattern. In most cases, DNA fragments smaller than $300 \mathrm{bp}$ were not considered.

\begin{tabular}{|c|c|c|}
\hline Digested with & Relevant feature $(s)$ & Go to: \\
\hline (1a) Sau3AI & Largest DNA fragment $<750$ bp Sau3AI (Group 1) & 2 \\
\hline (1b) Sau3AI & Largest DNA fragment $>950$ bp Sau3AI (Groups 2 and 3) & Table 2 \\
\hline (2a) $A s n \mathrm{I}$ & Not cut & 3 \\
\hline (2b) AsnI & Cut $(470-590$ bp and $900-960$ bp) & 6 \\
\hline (3a) KpnI & Cut $(410-470 \mathrm{bp}$ and $1000-1100 \mathrm{bp})$ & 4 \\
\hline (3b) $K p n I$ & Not cut & 8 \\
\hline (4a) $S p h \mathrm{I}$ & Cut & 5 \\
\hline (4b) SphI & Not cut: Streptomyces (56/103); Sporichthya (2/2) & \\
\hline (5a) $S p h \mathrm{I}$ & Cut (170-260 bp and 1010-1350 bp): Kitasatospora (12/12) & \\
\hline (5b) $S p h \mathrm{I}$ & Cut (390-450 bp and 1050-1110 bp): Streptomyces (47/103) & \\
\hline (6a) ScaI & Not cut & 7 \\
\hline (6b) ScaI & $\begin{array}{l}\text { Cut }(570-630 \text { bp and 850-900 bp): Gordonia (3/15); } \\
\text { Nocardia (20/25); Skermania (1/1) }\end{array}$ & \\
\hline (7a) $S p h \mathrm{I}$ & $\begin{array}{l}\text { Cut (280-310 bp and 890-920 bp): Glycomyces (3/3); } \\
\text { Nocardioides (1/5) }\end{array}$ & \\
\hline (7b) SphI & Not cut: Pseudonocardia (4/17) & \\
\hline (8a) PstI & Cut (400-430 bp and 1000-1050 bp): Nonomuraea $(10 / 15)$ & \\
\hline (8b) PstI & Not cut: Microbispora $(1 / 3)$ & \\
\hline
\end{tabular}


Table 2. Identification of the genera in Sau3AI Group 2

The number in parentheses after each genus name indicates how many species of that genus follow that specific pattern. In most cases, DNA fragments smaller than 300 bp were not considered.

\begin{tabular}{|c|c|c|}
\hline Digested with & Relevant feature(s) & Go to: \\
\hline (1a) Sau3AI & Cut (300-350 bp and 760-980 bp): Group 2 & 2 \\
\hline (1b) Sau3AI & Cut (990-1300 bp): Group 3 & Table 3 \\
\hline (2a) $A s n I$ & Cut $(470-590 \mathrm{bp}$ and $900-960 \mathrm{bp})$ & 3 \\
\hline (2b) AsnI & Not cut & 6 \\
\hline (3a) KpnI & Cut $(410-470 \mathrm{bp}$ and $1000-1100 \mathrm{bp})$ & 4 \\
\hline (3b) KpnI & Not cut & 5 \\
\hline (4a) HindIII & Cut (440 bp and $1070 \mathrm{bp})$ : Pseudonocardia (1/17) & \\
\hline (4b) HindIII & $\begin{array}{l}\text { Not cut: Nocardioides }(1 / 5) \text {; Prauserella }(1 / 1) \text {; } \\
\text { Saccharomonospora }(4 / 6)\end{array}$ & \\
\hline (5a) $S p h \mathrm{I}$ & Cut (270-280 bp and $900 \mathrm{bp}):$ Nocardioides $(2 / 5)$ & \\
\hline (5b) SphI & $\begin{array}{l}\text { Not cut: Actinoalloteichus (1/1); Actinopolyspora (1/1) } \\
\text { Saccharopolyspora (3/7); Thermocrispum }(1 / 1)\end{array}$ & \\
\hline (6a) HindIII & Cut (400-550 bp and 900-920 bp): Streptosporangium (3/12) & \\
\hline (6b) HindIII & Not cut & 7 \\
\hline (7a) $S p h \mathrm{I}$ & Cut (595-615 bp and 860-900 bp): Nocardiopsis $(2 / 13)$ & \\
\hline (7b) SphI & Not cut & 8 \\
\hline (8a) Pst I & Not cut: Thermobifida $(3 / 3)$ & \\
\hline (8b) PstI & Cut (415-460 bp and 995-1100 bp): Thermomonospora (1/2) & \\
\hline
\end{tabular}

Table 3. Identification of the genera in Sau3Al Group 3

The 16S rDNA of these genera is cut by AsnI and SphI.

\begin{tabular}{|c|c|c|}
\hline Digested with & Relevant feature(s) & Go to: \\
\hline (1a) AsnI & Cut $(470-590 \mathrm{bp}$ and $900-960 \mathrm{bp})$ & 2 \\
\hline (1b) $A s n I$ & Not cut & Table 5 \\
\hline (2a) SphI & Cut $(280-310 \mathrm{bp}$ and $890-920 \mathrm{bp})$ & 3 \\
\hline (2b) SphI & Not cut & Table 4 \\
\hline (3a) SnaBI & Not cut & 4 \\
\hline (3b) SnaBI & Cut $(470-510 \mathrm{bp}$ and $970-1000 \mathrm{bp})$ & 6 \\
\hline (4a) SalI & Not cut & 5 \\
\hline (4b) SalI & $\begin{array}{l}\text { Cut (540-560 bp and 900-1040 bp): Actinoplanes (7/21); } \\
\text { Micromonospora }(12 / 12) ; \text { Couchioplanes }(1 / 1) ; \text { Pilimelia } \\
\text { (2/2); Spirilliplanes }(1 / 1) \text {; Verrucosispora }(1 / 1) \text {; } \\
\text { Virgisporangium }(2 / 2)\end{array}$ & \\
\hline (5a) PvuII & Cut (560 bp and 970-980 bp): Dactylosporangium (6/6) & \\
\hline (5b) PvuII & $\begin{array}{l}\text { Not cut: Actinoplanes }(14 / 21) \text {; Asanoa (1/1); Catellatospora } \\
\text { (3/3); Catenuloplanes }(2 / 2)\end{array}$ & \\
\hline (6a) SalI & Cut (235-265 bp and $1215-1245 \mathrm{bp})$ & 7 \\
\hline (6b) SalI & Not cut & 9 \\
\hline (7a) AgeI & Cut (660-680 bp and $910-930 \mathrm{bp})$ & 8 \\
\hline (7b) AgeI & Not cut: Promicromonospora $(2 / 2)$ & \\
\hline (8a) Sst $\mathrm{I}$ & Cut (585 bp and $930 \mathrm{bp})$ : Hongia (1/1) & \\
\hline (8b) Sst I & Not cut: Kribbella (1/1); Nocardioides (1/5) & \\
\hline (9a) AgeI & Cut & 10 \\
\hline (9b) AgeI & Not cut: Oerskovia (3/3); Saccharopolyspora $(1 / 7)$ & \\
\hline (10a) AgeI & Produces two bands between $660 \mathrm{bp}$ and $910 \mathrm{bp}$ & 11 \\
\hline (10b) AgeI & Cut (230 bp and $1240 \mathrm{bp})$ : Intrasporangium (1/1) & \\
\hline (11a) AgeI & $670-680$ bp and $750-830 \mathrm{bp}$ : Kineosporia $(4 / 4)$ & \\
\hline (11b) AgeI & 660 bp and 910 bp: Nocardioides $(1 / 5)$ & \\
\hline
\end{tabular}


Nocardiaceae and the genera Gordonia and Skermania belong to the family Gordoniaceae. Both families are members of the suborder Corynebacterineae (Stackebrandt et al., 1997). The genus Glycomyces and Nocardioides luteus also formed a subgroup (Table 1, 7a), which could not be resolved. However, members of the genus Glycomyces do not exhibit mycelial fragmentation (Labeda et al., 1985), whereas fragmentation does occur in the members of the genus Nocardioides (Prauser, 1976), thus providing a simple way to distinguish between the genera in this subgroup.

Table 2 refers to the identification of the genera within Sau3AI Group 2. As with Group 1, not every genus was resolved (two small subgroups were generated). The first small subgroup comprised Nocardioides jensenii, Prauserella rugosa and four members of the genus Saccharomonospora (Table 2, 4b). Morphologically, these three genera are indistinguishable (Nocardioides jensenii is a member of the family Nocardioidaceae and Prauserella rugosa and Saccharomonospora are members of the family Pseudonocardiaceae (Stackebrandt et al., 1997). The second small subgroup comprised Actinoalloteichus cyanogriseus, Actinopolyspora halophila, Thermocrispum municipale and three members of the genus Saccharopolyspora (Table 2, 5b). Their morphological characteristics are sufficiently different to permit differentiation. The genus Actinoalloteichus forms aerial and substrate mycelium, both of which exhibit fragmentation (Tamura et al., 2000). The genus Actinopolyspora contains one species, a halophilic actinomycete, which forms aerial mycelium and produces a black pigment (Gochnauer et al., 1975). The genus Saccharopolyspora forms an extensive substrate mycelium that fragments and an aerial mycelium that does not fragment ( $\mathrm{Lu}$ et al., 2001). The genus Thermocrispum forms a white aerial mycelium and yellow to light-brown vegetative mycelium (Korn-Wendisch et al., 1995).

Sau3AI Group 3 comprised the largest group of filamentous actinomycete genera. This group is so large that the dichotomous key has been divided into three tables (Tables 3, 4 and 5). Table 3 shows the first part of the key, based on restriction by AsnI and SphI. Not every genus could be resolved. In most cases, an unknown isolate could, however, be placed in one of a small group of genera. Table 4 shows those genera, the 16S rDNA of which is restricted by AsnI, but not SphI. Although not every genus could be

Table 4. Identification of the genera in Sau3Al Group 3

The 16S rDNA of the genera listed in this table is cut by AsnI, but not SphI.

\begin{tabular}{|c|c|c|}
\hline Digested with & Relevant feature(s) & Go to: \\
\hline (1a) $K p n I$ & Cut $(410-470$ bp and $990-1100 \mathrm{bp})$ & 5 \\
\hline (1b) KpnI & Not cut & 2 \\
\hline (2a) HindIII & Cut & 3 \\
\hline (2b) HindIII & $\begin{array}{l}\text { Not cut: Actinosynnema (2/2); Pseudonocardia (3/17); Saccharo- } \\
\text { polyspora }(2 / 7)\end{array}$ & \\
\hline (3a) HindIII & 170-200 bp and 1270-1290 bp: Gordonia $(1 / 15)$ & \\
\hline (3b) HindIII & Two bands (460-570 bp, doublet) OR (460-570 bp and $890-990 \mathrm{bp})$ & 4 \\
\hline (4a) HindIII & 460 bp and 990 bp: Kibdelosporangium (1/1) & \\
\hline (4b) HindIII & $550-570$ bp and $890-990$ bp: Nocardia (5/25) & \\
\hline (5a) HindIII & Cut & 6 \\
\hline (5b) HindIII & Not cut & 8 \\
\hline (6a) HindIII & Produces at least one band $<250 \mathrm{bp}$ & 7 \\
\hline (6b) HindIII & $470-600$ bp and $910-970$ bp: Lentzea $(3 / 4)$ & \\
\hline (7a) ScaI & Cut (570-630 bp and 850-900 bp): Gordonia (8/15) & \\
\hline (7b) ScaI & Not cut: Pseudonocardia (1/17); Saccharomonospora (1/6) & \\
\hline (8a) SalI & Cut (540-560 bp and $950-990 \mathrm{bp})$ & 9 \\
\hline (8b) SalI & Not cut & 10 \\
\hline (9a) Psp1406I & Cut (440 bp and $1030 \mathrm{bp}):$ Streptoalloteichus (1/1) & \\
\hline (9b) Psp1406I & Not cut: Kutzneria $(2 / 2)$ & \\
\hline (10a) Psp1406I & Cut & 11 \\
\hline (10b) Psp1406I & $\begin{array}{l}\text { Not cut: Actinokineospora (5/5); Lechevalieria (2/2); Lentzea (1/4); } \\
\text { Pseudonocardia (4/17); Saccharothrix (7/7) }\end{array}$ & \\
\hline (11a) Psp1406I & Produces one band of 780 bp: Saccharomonospora (1/6) & \\
\hline (11b) Psp1406I & $\begin{array}{l}600 \text { bp and } 800 \text { bp: Amycolatopsis (11/12); Pseudonocardia (4/17); } \\
\text { Saccharopolyspora (1/7) }\end{array}$ & \\
\hline
\end{tabular}


Table 5. Identification of the genera in Sau3Al Group 3

The 16S rDNA of the genera listed in this table is not cut by AsnI.

\begin{tabular}{|c|c|c|}
\hline Digested with & Relevant feature(s) & Go to: \\
\hline (1a) KpnI & Cut $(410-470 \mathrm{bp}$ and $1000-1100 \mathrm{bp})$ & 2 \\
\hline (1b) KpnI & Not cut & 5 \\
\hline (2a) SphI & Cut (540 bp and 910-930 bp): Cryptosporangium (4/4) & \\
\hline (2b) SphI & Not cut & 3 \\
\hline (3a) PstI & Not cut & 4 \\
\hline (3b) PstI & $\begin{array}{l}\text { Cut, producing one band between } 400 \text { bp and } 465 \text { bp: Actinocorallia }(5 / 5) \text {; } \\
\text { Actinomadura (21/27); Saccharothrix (1/8); Spirillospora }(2 / 2)\end{array}$ & \\
\hline (4a) SnaB1 & Cut (500 bp and $930 \mathrm{bp}):$ Amycolatopsis (1/12) & \\
\hline (4b) SnaB1 & Not cut: Actinopolymorpha (1/1) & \\
\hline (5a) SphI & Cut $(595-630 \mathrm{bp}$ and $840-900 \mathrm{bp})$ & 6 \\
\hline (5b) SphI & Not cut & 7 \\
\hline (6a) PstI & Cut (500-580 bp and 860-900 bp): Nocardiopsis (7/13) & \\
\hline (6b) PstI & Not cut: Nocardiopsis (3/13); Streptomonospora (1/1) & \\
\hline (7a) PstI & Not cut & 8 \\
\hline (7b) PstI & $\begin{array}{l}\text { Cut }(430-590 \text { bp and } 870-1040 \text { bp): Acrocarpospora (1/2); Actinomadura } \\
\text { (2/27); Nocardiopsis (1/13); Nonomuraea }(5 / 15) ; \text { Planomonospora }(4 / 4) ; \\
\text { Planobispora }(2 / 2) ; \text { Streptosporangium }(8 / 9) ; \text { Thermomonospora }(1 / 2) ; \\
\text { Thermobispora }(1 / 1)\end{array}$ & \\
\hline (8a) HindIII & Cut (520-540 bp and 890-900 bp): Microtetraspora (3/3) & \\
\hline (8b) HindIII & $\begin{array}{l}\text { Not cut: Acrocarpospora }(1 / 2) ; \text { Actinomadura }(4 / 27) ; \text { Herbidospora }(1 / 1) ; \\
\text { Planotetraspora }(1 / 1) ; \text { Microbispora }(2 / 3) ; \text { Streptosporangium }(1 / 9)\end{array}$ & \\
\hline
\end{tabular}

individually identified, an isolate could be placed in one of a small group of genera. Table 5 shows the genera an isolate could belong to if its $16 \mathrm{~S}$ rDNA is not restricted by AsnI.

Although the method described here is intended to identify an unknown actinomycete to the genus level, in some cases it allows identification to the species level. Thus, Microbispora rosea (Table 1, 8b), Pseudonocardia kongjuensis (Table 2, 4a), Thermomonospora chromogena (Table 2, 8b), Hongia koreensis (Table 3, 8a), Intrasporangium calvum (Table 3, 10b), Nocardioides albus (Table 3, 11b), Gordonia rhizosphera (Table 4, 3a), Kibdelosporangium aridum (Table 4, 4a), Streptoalloteichus hindustanus (Table 4, 9a), Saccharomonospora xinjiangensis (Table 4, 11a), Amycolatopsis mediterranei (Table 5, 4a) and Actinopolymorpha singaporensis (Table 5, 4b) can be identified. Kribbella sandramycini and Nocardioides nitrophenolicus (Table 3, 8b) cannot be differentiated based on morphological differences (Park et al., 1999); both are members of the family Pseudonocardiaceae (Stackebrandt et al., 1997). Pseudonocardia sulfidoxydans and Saccharomonospora viridis (Table 4, 7b) also cannot be differentiated morphologically (Reichert et al., 1998; Runmao et al., 1988). Both genera are members of the family Nocardiaceae (Stackebrandt et al., 1997).

We investigated the possibility that the method could be used to group phylogenetically related Streptomyces species, but were unable to identify any significant groupings below the genus level.

\section{Identification of environmental isolates}

The most important restriction endonuclease used in this rapid identification method is Sau3AI. Fig. 2 shows the result of a Sau3AI digestion performed on the $16 \mathrm{~S}$ rDNA of seven environmental isolates. Lanes 3, 6, 8 and 9 show a doublet band in the size range $540-650 \mathrm{bp}$. The size of the doublet band indicates that the isolates represented in these lanes are part of Sau3AI Group 1 (Fig. 1) and therefore are

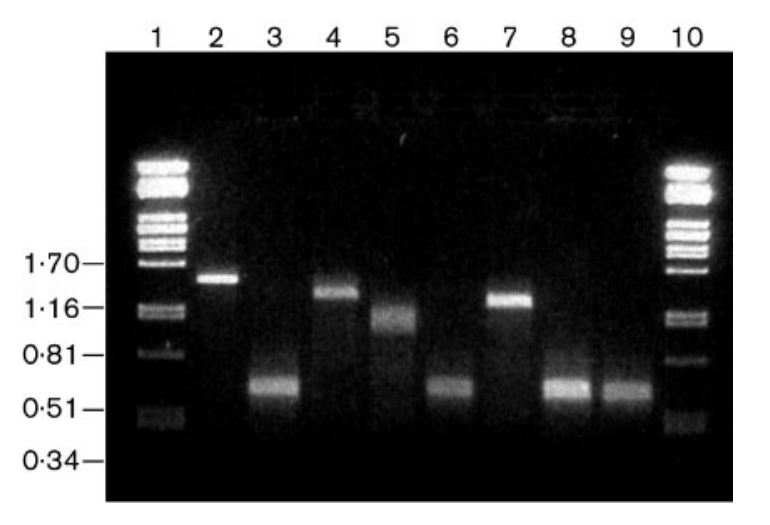

Fig. 2. Sau3Al endonuclease restriction analysis of seven unknown actinomycete strains. Lanes: 1 and 10, molecular size marker, $\lambda$ DNA digested with Pstl (sizes shown in kb); 2 , uncut 16S rDNA (1.5 kb); 3, strain 5; 4, strain N.CZ.8; 5, strain MTCT; 6, strain 17; 7, strain 23; 8, strain 30; 9, strain 37 . 
most likely to belong to the genus Streptomyces. However, the isolates in lanes 4, 5 and 7 (strains N.CZ.8, MTCT and 23 , respectively) show one band greater than $980 \mathrm{bp}$ in size. These isolates are non-Streptomyces species belonging to Sau3AI Group 3 (Fig. 1) and were investigated further.

Fig. 3(a) shows the results of a series of restriction endonuclease digestions of the $16 \mathrm{~S}$ rDNA of strain MTCT (Fig. 2, lane 5). Sau3AI restricted the DNA, producing one band greater than $980 \mathrm{bp}$ (lane 3). AsnI restricted the DNA producing two bands, 470-590 bp and 900-960 bp (lane 4). $S p h \mathrm{I}$ and KpnI did not restrict the DNA (lanes 5 and 6, respectively). HindIII restricted the DNA producing two bands, 550-570 bp and 890-990 bp in size (lane 8). Based on the analysis of the fragment patterns in Fig. 3(a) and the dichotomous keys in Tables 1, 2, 3 and 4, strain MTCT belongs to the genus Nocardia. If strain MTCT had been characterized by chemotaxonomic analysis (DAP isomer and whole-cell sugar pattern), it could have been assigned to any of the genera Amycolata, Amycolatopsis, Nocardia, Pseudonocardia or Saccharopolyspora (taking colony morphology into account).

Fig. 3(b) shows the results of a series of restriction endonuclease digestions of the 16S rDNA of strain N.CZ.8 (Fig. 2, lane 4). Sau3AI restricted the DNA, producing one band greater than $980 \mathrm{bp}$ (lane 3). AsnI and KpnI did not restrict the DNA (lanes 4 and 6, respectively). SphI restricted the DNA producing two bands, 595-630 bp and 840-900 bp (lane 5). PstI restricted the DNA producing two bands, 500-580 bp and 860-900 bp (lane 9). Based on the analysis of the fragment patterns in Fig. 3(b) and the dichotomous keys in Tables 1, 2 and 5, strain N.CZ.8 belongs to the genus Nocardiopsis. If DAP-isomer and whole-cell sugar pattern analyses had been carried out, strain N.CZ.8 could have been assigned to the genus Nocardiopsis or Thermoactinomyces (taking colony characteristics into consideration).

Fig. 3(c) shows the results of a series of restriction endonuclease digestions of the 16S rDNA of strain 23 (Fig. 2, lane 7). Sau3AI restricted the DNA, producing one band greater than $980 \mathrm{bp}$ (lane 3). AsnI did not restrict the DNA (lane 4). KpnI restricted the DNA producing two bands of 410-470 bp and 1000-1100 bp (lane 6). SphI did not restrict the DNA (lane 5). PstI restricted the DNA producing two bands, one of which was in the size range 400-465 bp (lane 9). Based on the analysis of the fragment patterns in Fig. 3(c) and the dichotomous keys in Tables 1,2 and 5, strain 23 could belong to one of the following genera: Actinocorallia, Actinomadura, Saccharothrix or Spirillospora. Based on an examination of colony morphology using a light microscope, the non-fragmenting, asporangiate strain 23 cannot belong to the genus Saccharothrix, which exhibits aerial and substrate mycelium fragmentation (Labeda et al., 1984), nor the sporangiate genus Spirillospora (Vobis \& Kothe, 1989). Therefore, strain 23 belongs to either the genus Actinocorallia or the genus Actinomadura. In this case, a similar result would have been obtained by DAP-isomer and whole-cell sugar pattern analyses.

We have developed a method to identify rapidly environmental Streptomyces isolates using only four restriction

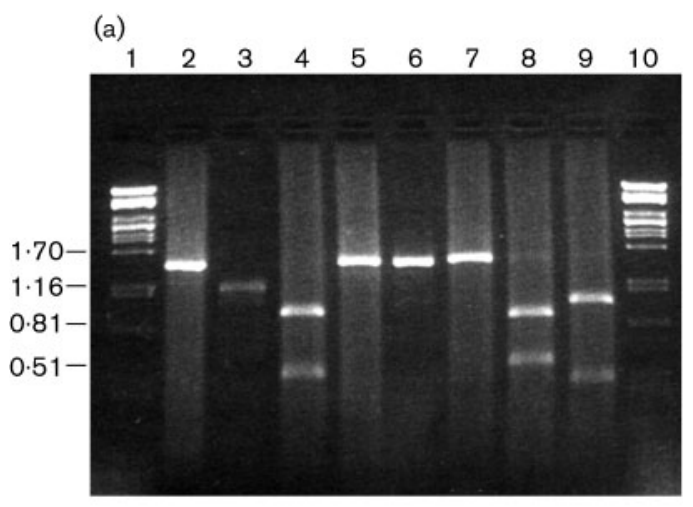

(b)

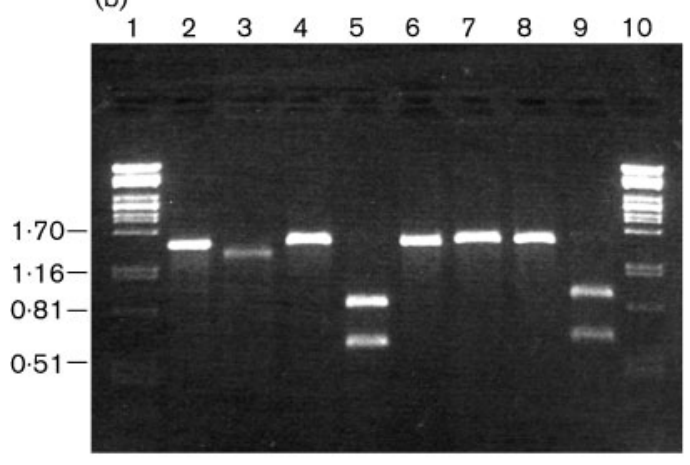

(c)

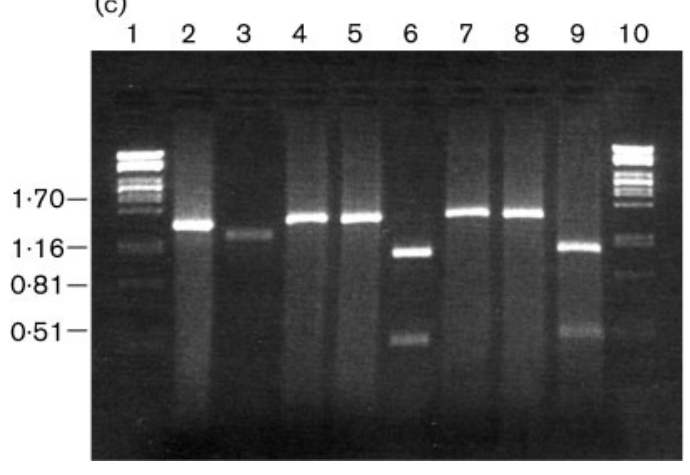

Fig. 3. (a) Restriction analysis of the $16 \mathrm{~S}$ rDNA of strain MTCT. Lanes: 1 and 10, molecular size marker, $\lambda$ DNA digested with Pstl (sizes shown in kb); 2, uncut MTCT 16S rDNA (1.5 kb); 3, Sau3Al; 4, Asnl; 5, Sphl; 6, Kpnl; 7, Sall; 8, Hindlll; 9, Pstl. (b) Restriction analysis of the 16S rDNA of strain N.CZ.8. Lanes 1 and 10, molecular size marker, $\lambda$ DNA digested with Pstl (sizes shown in kb); 2, uncut N.CZ.8 16S rDNA (1.5 kb); 3, Sau3Al; 4, Asnl; 5, Sphl; 6, Kpnl; 7, Sall; 8. Hindlll; 9, Pstl. (c) Restriction analysis of the 16S rDNA of strain 23. Lanes: 1 and 10, molecular size marker, $\lambda$ DNA digested with Pstl (sizes shown in kb); 2, uncut strain $2316 \mathrm{~S}$ rDNA (1.5 kb); 3, Sau3Al; 4, Asnl; 5, Sphl; 6, Kpnl; 7, Sall; 8, Hindlll; 9, Pstl. 
endonucleases. Non-Streptomyces species were identified rapidly to a specific genus or a small subgroup of genera (in which case, other readily available information, such as colony morphology, was sufficient to restrict further the number of genus possibilities). The online version of this article (http://ijs.sgmjournals.org) provides access to an interactive Microsoft PowerPoint (version 5.0) version of this method.

It would be logical to extend this method to the analysis of $23 \mathrm{~S}$ rDNA sequences to try and resolve the genera in the various subgroups shown in Tables 1-5. However, at present, this approach would be hampered by the paucity of $23 \mathrm{~S}$ rDNA sequence data in the public databases. Thus, it will be impossible to expand this method until many more $23 \mathrm{~S}$ rDNA sequences are made available. Nevertheless, as presented, the method allows the determination of sufficient information about an environmental isolate to decide whether it is worth pursuing as a research culture.

In laboratories in developed countries, a partial $16 \mathrm{~S}$ rDNA sequence of a new actinomycete isolate can be obtained quickly and at low cost to give an unambiguous identification of the genus to which the isolate belongs. This is certainly not the case in developing countries, such as South Africa, where high sequencing costs and possible restricted access to sequencing facilities preclude the use of $16 \mathrm{~S}$ rDNA sequencing as a routine genus-identification tool.

\section{ACKNOWLEDGEMENTS}

Andrew Cook holds a Benfara Scholarship, a University Scholarships Committee Award and a Harry Crossley Foundation Bursary from the University of Cape Town. Paul Meyers is the recipient of research grants from the University Research Committee (University of Cape Town) and the Medical Research Council of South Africa.

\section{REFERENCES}

Alves, A., Santos, O., Henriques, I. \& Correia, A. (2002). Evaluation of methods for molecular typing and identification of members of the genus Brevibacterium and other related species. FEMS Microbiol Lett 213, 205-211.

Anderson, A. S. \& Wellington, E. M. H. (2001). The taxonomy of Streptomyces and related genera. Int J Syst Evol Microbiol 51, 797814.

Atlas, R. M. (1993). Handbook of Microbiological Media. Edited by L. C. Parks. Boca Raton: CRC Press.

Beyazova, M. \& Lechevalier, M. P. (1993). Taxonomic utility of restriction endonuclease fingerprinting of large DNA fragments from Streptomyces strains. Int J Syst Bacteriol 43, 674-682.

Elander, R. P. (1987). Microbial screening, selection and strain improvement. In Basic Biotechnology, pp. 217-251. Edited by J. Bu'Lock \& B. Kristiansen. London: Academic Press.

Euzéby, J. P. (2002). List of Bacterial Names with Standing in Nomenclature (http://www.bacterio.cict.fr/).

Gochnauer, M. B., Leppard, G. G., Komaratat, P., Kates, M., Novitsky, T. \& Kushner, D. J. (1975). Isolation and characterization of Actinopolyspora halophila, gen. et sp. nov., an extremely halophilic actinomycete. Can J Microbiol 21, 1500-1511.

Gurtler, V., Wilson, V. A. \& Mayall, B. C. (1991). Classification of medically important clostridia using restriction endonuclease site differences of PCR-amplified 16S rDNA. J Gen Microbiol 137, 2673-2679.

Harvey, I., Cormier, Y., Beaulieu, C., Akimov, V. N., Mériaux, A. \& Duchaine, C. (2001). Random amplified ribosomal DNA restriction analysis for rapid identification of thermophilic actinomycete-like bacteria involved in hypersensitivity pneumonitis. Syst Appl Microbiol 24, 277-284.

Kohler, G., Ludwig, W. \& Schleifer, K. H. (1991). Differentiation of lactococci by rRNA gene restriction analysis. FEMS Microbiol Lett 84, 307-312.

Korn-Wendisch, F., Rainey, F., Kroppenstedt, R. M., Kempf, A., Majazza, A., Kutzner, H. J. \& Stackebrandt, E. (1995). Thermocrispum gen. nov., a new genus of the order Actinomycetales, and description of Thermocrispum municipale sp. nov. and Thermocrispum agresta sp. nov. Int J Syst Bacteriol 45, 67-77.

Labeda, D. P., Testa, R. T., Lechevalier, M. P. \& Lechevalier, H. A. (1984). Saccharothrix: a new genus of the Actinomycetales related to Nocardiopsis. Int J Syst Bacteriol 34, 426-431.

Labeda, D. P., Testa, R. T., Lechevalier, M. P. \& Lechevalier, H. A. (1985). Glycomyces, a new genus of the Actinomycetales. Int J Syst Bacteriol 35, 417-421.

Lacey, J. (1973). Actinomycetes in soils, composts and fodders. In Actinomycetales: Characteristics and Practical Importance, pp. 231-251. Edited by G. Sykes \& F. A. Skinner. London: Academic Press.

Laurent, F. J., Provost, F. \& Boiron, P. (1999). Rapid identification of clinically relevant Nocardia species to genus level by $16 \mathrm{~S}$ rRNA gene PCR. J Clin Microbiol 37, 99-102.

Lazzarini, A., Cavaletti, L., Toppo, G. \& Marinelli, F. (2000). Rare genera of actinomycetes as potential producers of new antibiotics. Antonie van Leeuwenhoek 78, 399-405.

Lechevalier, H. A. (1989). A practical guide to generic identification of actinomycetes. In Bergey's Manual of Systematic Bacteriology, vol. 4, pp. 2344-2347. Edited by S. T. Williams, M. E. Sharpe \& J. G. Holt. Baltimore: Williams \& Wilkins.

Lu, Z., Liu, Z., Wang, L., Zhang, Y., Qi, W. \& Goodfellow, M. (2001). Saccharopolyspora flava sp. nov. and Saccharopolyspora thermophila sp. nov., novel actinomycetes from soil. Int J Syst Evol Microbiol 51, 319-325.

Mehling, A., Wehmeier, U. F. \& Piepersberg, W. (1995). Nucleotide sequences of streptomycete $16 \mathrm{~S}$ ribosomal DNA: towards a specific identification system for streptomycetes using PCR. Microbiology 141, 2139-2147.

Park, Y.-H., Yoon, J.-H., Shin, Y. K., Suzuki, K.-i., Kudo, T., Seino, A., Kim, H.-J., Lee, J.-S. \& Lee, S. T. (1999). Classification of 'Nocardioides fulvus' IFO 14399 and Nocardioides sp. ATCC 39419 in Kribbella gen. nov., as Kribbella flavida sp. nov. and Kribbella sandramycini sp. nov. Int J Syst Bacteriol 49, 743-752.

Prauser, H. (1976). Nocardioides, a new genus of the order Actinomycetales. Int J Syst Bacteriol 26, 58-65.

Reichert, K., Lipski, A., Pradella, S., Stackebrandt, E. \& Altendorf, K. (1998). Pseudonocardia asaccharolytica sp. nov. and Pseudonocardia sulfidoxydans sp. nov., two new dimethyl disulfidedegrading actinomycetes and emended description of the genus Pseudonocardia. Int J Syst Bacteriol 48, 441-449.

Runmao, H., Lin, C. \& Guizhen, W. (1988). Saccharomonospora cyanea sp. nov. Int J Syst Bacteriol 38, 444-446.

Shirling, E. B. \& Gottlieb, D. (1966). Methods for characterization of Streptomyces species. Int J Syst Bacteriol 16, 313-340. 
Soini, H., Bottger, E. C. \& Viljanen, M. K. (1994). Identification of mycobacteria by PCR-based sequence determination of the 32kilodalton-protein gene. J Clin Microbiol 32, 2944-2947.

Stackebrandt, E., Rainey, F. A. \& Ward-Rainey, N. L. (1997). Proposal for a new hierarchic classification system, Actinobacteria classis nov. Int J Syst Bacteriol 47, 479-491.

Steingrube, V. A., Gibson, J. L., Brown, B. A., Zhang, Y., Wilson, R. W., Rajagopalan \& Wallace, R. J., Jr (1995a). PCR amplification and restriction analysis of a 65-kilodalton heat shock protein gene sequence for taxonomic separation of rapidly growing mycobacteria. J Clin Microbiol 33, 149-153.

Steingrube, V. A., Brown, B. A., Gibson, J. L. \& 7 other authors (1995b). DNA amplification and restriction endonuclease analysis for differentiation of 12 species and taxa of Nocardia, including recognition of four new taxa within the Nocardia asteroides complex. J Clin Microbiol 33, 3096-3101.

Steingrube, V. A., Wilson, R. W., Brown, B. A., Jost, K. C., Jr, Blacklock, Z., Gibson, J. L. \& Wallace, R. J., Jr (1997). Rapid identification of the clinically significant species and taxa of aerobic actinomycetes, including Actinomadura, Gordona, Nocardia, Rhodococcus, Streptomyces, and Tsukamurella isolates, by DNA amplification and restriction endonuclease analysis. $J$ Clin Microbiol 35, 817-822.
Tamura, T., Hayakawa, M. \& Hatano, K. (1999). Sporichthya brevicatena sp. nov. Int J Syst Evol Microbiol 49, 1779-1784.

Tamura, T., Zhiheng, L., Yamei, Z. \& Hatano, K. (2000). Actinoalloteichus cyanogriseus gen. nov., sp. nov. Int J Syst Evol Microbiol 50, 1435-1440.

Telenti, A., Marchesi, F., Balz, M., Bally, F., Bottger, E. C. \& Bodmer, T. (1993). Rapid identification of mycobacteria to the species level by polymerase chain reaction and restriction enzyme analysis. J Clin Microbiol 31, 175-178.

Vobis, G. \& Kothe, H.-W. (1989). Genus Spirillospora Couch 1963, $61^{\mathrm{AL}}$. In Bergey's Manual of Systematic Bacteriology, vol. 4, pp. 2543-2545. Edited by S. T. Williams, M. E. Sharpe \& J. G. Holt. Baltimore: Williams \& Wilkins.

Watve, M. G., Tickoo, R., Jog, M. M. \& Bhole, B. D. (2001). How many antibiotics are produced by the genus Streptomyces? Arch Microbiol 176, 386-390.

Weisburg, W. G., Barns, S. M., Pelletier, D. A. \& Lane, D. J. (1991). $16 \mathrm{~S}$ ribosomal DNA amplification for phylogenetic study. J Bacteriol 173, 697-703.

Wilson, R. W., Steingrube, V. A., Brown, B. A. \& Wallace, R. J., Jr (1998). Clinical application of PCR-restriction enzyme pattern analysis for rapid identification of aerobic actinomycete isolates. J Clin Microbiol 36, 148-152. 